\title{
Use of a novel cassette to label phenotypically a cryptic plasmid of Bacillus subtilis and map loci involved in its stable maintenance
}

\author{
ANDRew P. Gleave, ${ }^{1,2} \uparrow$ ANDrew Mountain ${ }^{2}$ and Christopher M. Thomas ${ }^{1 *}$ \\ ${ }^{1}$ School of Biological Sciences, University of Birmingham, PO Box 363, Birmingham B15 2TT, UK \\ ${ }^{2}$ Celltech Limited, 216-222 Bath Road, Slough SLI 4EN, UK
}

(Received 18 September 1989; revised 11 January 1990; accepted 1 February 1990)

\begin{abstract}
In order to facilitate studies on the maintenance of cryptic plasmids from Gram-positive bacteria we have constructed a novel cassette cAPG1000 (5.0 kb) which carries both a selectable marker (chloramphenicol resistance from Staphylococcus aureus plasmid pC194) and a screenable marker (the $x y l E$ gene from the TOL plasmid of Pseudomonas putida expressed from a cloned promoter of Bacillus phage SPO2) and which is flanked by terminators to prevent transcription from the cassette activating or inhibiting loci adjacent to the site of insertion. To demonstrate the usefulness of this cassette we have mapped loci required for stable maintenance of an $8.6 \mathrm{~kb}$ cryptic plasmid endogenous to Bacillus subtilis (pPOD2000) from the properties of CAPG1000 insertion and insertion/deletion derivatives. We have identified the replication region as well as separate regions required for segregational and structural stability. The segregational mechanism is very efficient since it allows no detectable loss despite the fact that bacteria carrying the plasmid have a greatly increased mean generation time.
\end{abstract}

\section{Introduction}

Bacterial plasmids are widely exploited as vectors for gene cloning and genetic manipulation. Naturally occurring plasmids, although often very stable, are rarely immediately useful as vectors and must themselves be manipulated to produce optimal vector properties. Such manipulation can result in disruption of stable maintenance functions unless these have already been mapped. Analysis of cryptic plasmids requires the addition of phenotypic markers to facilitate detection as well as creation of easily mapped mutations to locate stability functions. To allow phenotypic labelling and mutagenesis to be carried out simultaneously and to simplify testing of mutant stability we have constructed a novel cassette and applied it to the study of a cryptic plasmid endogenous to Bacillus subtilis.

B. subtilis has many potential advantages as a host for the industrial exploitation of cloned genes. It is apparently completely harmless to humans, facilitating the preparation of safe pharmaceutical and therapeutic products. Also it secretes proteins efficiently into the

$\dagger$ Present address: Entomology Division, Department of Scientific and Industrial Research, Mount Albert Research Centre, Private Bag, Auckland, New Zealand. medium, which can limit the intracellular accumulation of gene products toxic to the bacteria and which may enhance the recovery of products in a soluble form (Palva et al., 1983) and reduce downstream processing costs. However a number of factors have limited the use of $B$. subtilis as a host for recombinant DNA. Among these has been the instability, both structural (Gryczan \& Dubnau, 1978; Kreft et al., 1982) and segregational (Grandi et al., 1981; Kreft et al., 1982; Yoshimura et al., 1983) of recombinant plasmids in this species. It has been proposed that a major cause of this instability is the fact that the plasmids from Staphylococcus aureus which almost exclusively have formed the basis of $B$. subtilis cloning vehicles (Ehrlich 1977, 1978; Gryczan \& Dubnau, 1978; Gryczan et al., 1980) replicate via a rolling circle mechanism (te Riele et al., 1986a, $b$; Gros et al., 1987). In $B$. subtilis, where lagging strand synthesis of the plasmids is not generally initiated efficiently, singlestranded plasmid DNA accumulates (te Riele et al., $1986 a$ ) and appears to stimulate deletion formation by slipped mispairing (Ehrlich et al., 1986). However, even with plasmids such as pUB110 which as native plasmids show very little accumulation of single-stranded DNA in $B$. subtilis, insertion of foreign DNA can disrupt the normal replication and stable inheritance processes and lead to both structural and segregational instability (Bron 
\& Luxen, 1985; Viret \& Alonso, 1987). It is essential therefore to characterize fully a potential plasmid vector system with respect to the effect that insertion of foreign DNA has on plasmid functions and the stability of the cloned DNA.

To provide the basis of an alternative cloning vector system for this species we have initiated studies on the replication and stable inheritance functions of a lowcopy-number endogenous plasmid from a strain of $B$. subtilis isolated by Tanaka et al. (1977) since such a plasmid should already be well adapted for stable maintenance in its host species. Our initial characterization of the plasmid obtained raised some doubt in our minds as to whether we really had pLS14, the plasmid requested, so we have designated it pPOD2000. It may be related to but is not identical to two plasmids from Bacillus amyloliquefaciens which have been partially characterized (Bron et al., 1987; Chang et al., 1987). Plasmid pPOD2000 is maintained at relatively low copy number (approximately five copies per chromosome equivalent) and has no directly selectable markers. In this paper we describe construction of the novel cassette and its use to study the maintenance functions of pPOD2000.

\section{Methods}

Bacterial strains and growth conditions. Escherichia coli $\mathrm{K} 12$ strain C600 (thr-1 leu-6 thi-1 lacYl supE44 tonA2l $\mathrm{galE}^{+} \mathrm{T}^{+} \mathrm{K}^{-}$) (from $\mathrm{M}$. Rosenberg, SK\&F Laboratories, Swedeland, Pennsylvania, USA) and B. subtilis 1A289 (aro-1906 metB5 sacA321 amyE) (from Bacillus Genetic Stock Center, Ohio State University, Columbus, Ohio, USA), PLS1 (arg-15 leuA8 thrA stp recE4 $\mathrm{r}^{-} \mathrm{m}^{-}$) (Ostroff \& Pène, 1983) and BD224 (trpC2 thr-5 recE4) (1A46 from Bacillus Genetic Stock Center, see above) were used. Bacteria were grown at $37^{\circ} \mathrm{C}$ in $\mathrm{L}$ broth (Kahn et al., 1979) or on $\mathrm{L}$ agar, consisting of $\mathrm{L}$ broth supplemented with $1.5 \%$ (w/v) agar. Other media are described where appropriate. Antibiotic resistance conferred by plasmids was selected by addition of benzylpenicillin, sodium salt $\left(300 \mu \mathrm{g} \mathrm{ml}^{-1}\right.$ in solid and $150 \mu \mathrm{g} \mathrm{ml}^{-1}$ in liquid media) for $\mathrm{Pn}^{\mathrm{R}}$; tetracycline hydrochloride $\left(20 \mu \mathrm{g} \mathrm{ml}^{-1}\right)$ for $\mathrm{Tc}^{\mathrm{R}}$; chloramphenicol $\left(5 \mu \mathrm{g} \mathrm{ml}^{-1}\right.$ for $E$. coli and 5-20 $\mu \mathrm{g} \mathrm{ml}^{-1}$ for B. subtilis) for $\mathrm{Cm}^{\mathrm{R}}$; and kanamycin sulphate $\left(30 \mu \mathrm{g} \mathrm{m}^{-1}\right)$ for $\mathrm{Km}^{\mathrm{R}}$.

Plasmids. Plasmids used in this work and which have previously been described are listed in Table 1. Plasmids constructed during the course of this work are described in the text or the Figures.

DNA isolation, analysis and genetic manipulation. Plasmid DNA isolation on both small and large scales was carried out by the method of Birnboim \& Doly (1979). For E. coli, lysozyme was omitted from the lysis buffer and alkaline SDS was added immediately after resuspension. For $B$. subtilis, bacteria were incubated with lysozyme for $15 \mathrm{~min}$ at $37^{\circ} \mathrm{C}$ prior to addition of alkaline SDS. Further purification was achieved by isopycnic centrifugation in $\mathrm{CsCl}$ /ethidium bromide gradients. Routine analysis and manipulation of plasmid DNA was carried out as described by Maniatis et al. (1982). DNA sequence analysis was carried out as described by Maxam \& Gilbert (1980) with modifications as described previously (Smith \& Thomas, 1984).

Transformation of bacteria. E. coli was made competent for transformation by standard $\mathrm{CaCl}_{2}$ treatment (Meyer et al., 1977). Transformation of $B$. subtilis protoplasts was achieved by a variation on standard methods developed by A. Mountain. L broth $(100 \mathrm{ml})$ was inoculated with bacteria from a fresh plate and the culture grown to $\mathrm{OD}_{650}=0.4$. The bacteria were harvested and resuspended in $7.5 \mathrm{ml}$ SPA ( $5: 4: 1$, by vol, of $2 \times$ SSM, $4 \times$ Penassay broth, $5 \%$, w/v, BSA; $2 \times \mathrm{SSM}$ is $1 \mathrm{M}$-sucrose, $40 \mathrm{~mm}$-maleic acid, $40 \mathrm{mM}-\mathrm{MgCl}_{2}$ ). Then $0.4 \mathrm{ml}$ of freshly made and filter-sterilized lysozyme solution (20 mg ml-1 in SPA) was added and the mixture incubated at $37^{\circ} \mathrm{C}$ with gentle shaking. Phase-contrast microscopy was used to monitor protoplast formation, which generally took about $60 \mathrm{~min}$. Protoplasts were harvested by centrifugation at $4{ }^{\circ} \mathrm{C}$, resuspended in $7.5 \mathrm{ml} \mathrm{SPA}$ by gentle pipetting and then reharvested and resuspended as before. Using $13.5 \mathrm{ml}$ disposable conical tubes (Falcon or Sterilin) $0.5 \mathrm{ml}$ of protoplast suspension was mixed with up to $50 \mu \mathrm{l}$ DNA solution and $1.5 \mathrm{ml} \mathrm{30 \% (w/v)} \mathrm{PEG} \mathrm{6000.} \mathrm{After} 2-5 \mathrm{~min}$ at $20^{\circ} \mathrm{C}, 5 \mathrm{ml} \mathrm{SPA}$ was added and after mixing by inversion, the protoplasts were harvested by centrifugation at 4300 r.p.m. for $15 \mathrm{~min}$. The SPA/PEG supernatant was removed and the protoplast pellet resuspended in $2 \mathrm{ml} \mathrm{SPA}$ and

Table 1. Previously described plasmids used in this study

\begin{tabular}{|c|c|c|c|c|}
\hline Plasmid & $\begin{array}{l}\text { Size } \\
(\mathbf{k b})\end{array}$ & Replicon & Properties & Reference \\
\hline pC194 & $2 \cdot 9$ & pC194 & $\mathrm{Cm}^{\mathrm{R}}$ & Ehrlich (1977) \\
\hline pCPP-3 & 5.6 & pMB1/pUB 110 & $\mathrm{Km}^{\mathrm{R}}$ & Band et al. (1983) \\
\hline pCT571 & $9 \cdot 5$ & $\mathrm{pSC} 101$ & $\mathrm{Km}^{\mathrm{R}} \mathrm{Tc}^{\mathrm{R}}$ & $\begin{array}{l}\text { Hasnain \& } \\
\text { Thomas (1986) }\end{array}$ \\
\hline pDS3 & $2 \cdot 5$ & pl5A & $\mathrm{Cm}^{\mathrm{R}}$ & Thomas (1981) \\
\hline pHV60 & $5 \cdot 55$ & pMB1 & $\begin{array}{l}\mathrm{Cm}^{\mathrm{R}} \mathrm{Tc}^{\mathrm{R}} \mathrm{Pn}^{\mathrm{R}} \\
=\mathrm{pHV} 32\end{array}$ & $\begin{array}{l}\text { Primrose \& } \\
\text { Ehrlich (1981) }\end{array}$ \\
\hline pKK223-3 & 4.6 & pMB1 & $\mathrm{Pn}^{\mathrm{R}}$ & Brosius \& Holy (1984) \\
\hline pPL608 & 5.0 & pUB 110 & $\mathrm{Km}^{\mathrm{R}} \mathrm{Cm}^{\mathrm{R}}$ & Williams et al. (1981) \\
\hline pPOD2000 & 8.6 & pPOD2000 & Cryptic (pLS14) & Tanaka et al. (1977) \\
\hline pRK2501 & 11.0 & RK2 & $\mathrm{Km}^{\mathrm{R}} \mathrm{Tc}^{\mathrm{R}}$ & Kahn et al. (1979) \\
\hline pSRW40 & 6.9 & pMB1 & $\mathbf{P n}^{\mathbf{R}}$ & Warne (1986) \\
\hline pUB 110 & $4 \cdot 5$ & pUB110 & $\mathrm{Km}^{\mathrm{R}}$ & $\begin{array}{l}\text { Gryczan \& Dubnau } \\
(1978)\end{array}$ \\
\hline pUC7 & $2 \cdot 7$ & pMB1 & $\mathbf{P n}^{\mathrm{R}}$ & Vieira \& Messing (1982) \\
\hline
\end{tabular}


incubated at $37{ }^{\circ} \mathrm{C}$ for $2-3 \mathrm{~h}$ with gentle shaking to allow expression of antibiotic resistance markers. Aliquots of $0.1 \mathrm{ml}$ were spread on DGSA regeneration/selection plates and incubated at $37^{\circ} \mathrm{C}$ for up to $3 \mathrm{~d}$. DGSA consists of, per litre : $280 \mathrm{ml}$ protoplast agar, $230 \mathrm{ml} 2 \mathrm{M}$-sodium succinate $\mathrm{pH} 7 \cdot 3,40 \mathrm{ml} \mathrm{3} \%(\mathrm{w} / \mathrm{v}) \mathrm{KH}_{2} \mathrm{PO}_{4}, 40 \mathrm{ml} 7 \%(\mathrm{w} / \mathrm{v}) \mathrm{K}_{2} \mathrm{HPO}_{4}$, $320 \mathrm{ml} \mathrm{2.8 \%}(\mathrm{w} / \mathrm{v})$ soluble starch, $20 \mathrm{ml} \mathrm{20 \%}(\mathrm{w} / \mathrm{v})$ glucose, $10 \mathrm{ml} 1 \mathrm{M}-$ $\mathrm{MgCl}_{2}, 40 \mathrm{ml} \mathrm{10 \% (w/v)} \mathrm{gelatin,} 8 \mathrm{ml} \mathrm{5 \%}(\mathrm{w} / \mathrm{v}) \mathrm{BSA}$. Protoplast agar contains, per $280 \mathrm{ml}: 10.5 \mathrm{~g}$. Difco agar, $4.9 \mathrm{~g}$ Difco Casamino acids, $4.9 \mathrm{~g}$ Difco Yeast extract. While this method was necessary for transformation with ligated DNA, a scaled-down version using microfuge tubes and $50 \mu \mathrm{l}$ of protoplast suspension with $2-5 \mu \mathrm{I}$ DNA, $150 \mu \mathrm{l}$ PEG and $500 \mu \mathrm{l} \mathrm{SPA}$ could be used simply to transfer plasmids into a new strain.

Estimation of plasmid stability. Stationary-phase cultures of bacteria carrying the plasmid under test were grown with antibiotic selection and then diluted $10^{6}$-fold into $50 \mathrm{ml}$ nonselective medium in $250 \mathrm{ml}$ conical flasks and grown to saturation with shaking at $37^{\circ} \mathrm{C}$. This gives approximately 20 generations of growth. Dilution and growth to stationary phase were repeated four more times to give 100 generations of unselected growth. Culture samples were withdrawn at convenient points from 0 to 100 generations and spread on nonselective agar after suitable dilution to give approximately 100 colonies per plate. Incubation at $37^{\circ} \mathrm{C}$ was continued until colonies were $2-3 \mathrm{~mm}$ in diameter, at which stage the plates were sprayed with a $0.5 \mathrm{M}$-catechol solution (Zukowski et al., 1983). After $5 \mathrm{~min}$ the colonies were scored $\mathrm{XylE}^{+}$or $\mathrm{XylE}^{-}$. A selection of colonies of both phenotype (if both were found) were then replica-plated to test for $\mathrm{Cm}^{\mathrm{R}}$.

Determination of $X y l E$ activity. Catechol 2,3-oxygenase (XylE) activity was assayed by a modification of the method of Sala-Trepat \& Evans (1971). Bacteria from a $30 \mathrm{ml}$ saturated culture were harvested and resuspended in $1.2 \mathrm{ml} 0.1 \mathrm{M}$-sodium phosphate buffer, $\mathrm{pH} 7.0$, $0.15 \mathrm{ml}$ acetone and $0.15 \mathrm{ml}$ lysozyme solution' $\left(1 \mathrm{mg} \mathrm{ml}^{-1}\right)$, transferred to a microfuge tube and incubated at $37^{\circ} \mathrm{C}$ for $10 \mathrm{~min}$. After disruption by ultrasonic treatment $(2 \times 30 \mathrm{~s})$ on ice, cell debris was pelleted by centrifugation at $4{ }^{\circ} \mathrm{C}$ in a microfuge. Enzyme activity in the supernatant was assayed by measuring the rate of change of absorbance at $375 \mathrm{~nm}$ when a known volume of extract (usually $10 \mu \mathrm{l}$ ) was added to $3.0 \mathrm{ml} 0.67 \mathrm{~mm}$-catechol in $0.1 \mathrm{M}$-sodium phosphate buffer $\mathrm{pH} 7.0$ in a $3 \mathrm{ml}$ cuvette with $1 \mathrm{~cm}$ light path. Protein concentration in the extracts was determined by the biuret reaction (Gornall et al., 1949).

\section{Results}

Construction of a novel cassette for insertional mutagenesis of plasmids in Gram-positive bacteria

Construction of the cassette is summarized in Fig. 1. The two primary attributes which we required in the cassette were a selectable marker to allow direct selection for the presence of the plasmid into which the cassette was inserted and a screenable marker to facilitate tests on plasmid stability. For these we chose the chloramphenicol resistance gene, cat or $\mathrm{Cm}^{\mathrm{R}}$, from $S$. aureus plasmid pC194, which is known to be expressed in $B$. subtilis (Ehrlich, 1977) and expression of the $x y l E$ gene from the TOL plasmid of Pseudomonas putida, whose ribosomebinding site contains strong complementarity to the $16 \mathrm{~S}$ rRNA of $B$. subtilis and which is known to be expressed efficiently if transcribed in B. subtilis (Zukowski et al., 1983). Since the $x y l E$ gene comes from the centre of an operon it lacks its own promoter and so to achieve efficient expression, heterologous promoters $t a c$ and $t r p$ from $E$. coli, and a SPO2 Bacillus phage promoter, all of which are known to function in $B$. subtilis (Penschke $e t$ al., 1985; Williams et al., 1981), were inserted upstream of the $x y l E$ structural gene by linearizing pAPG7 at the $X h o I$ site, filling in the sticky ends and ligating to bluntended promoter-containing fragments. We found that only the SPO2 promoter gave sufficient $x y l E$ expression to allow easy screening for the presence of plasmids in $B$. subtilis.

In addition we flanked the cassette with transcriptional terminators to ensure that insertion of the cassette had no deleterious effect other than that due to its disruption of the continuity of the plasmid backbone. The terminators used were the dual E. coli $r r n B \mathrm{t}_{1} \mathrm{t}_{2}$ and $\lambda \mathrm{t}_{0}$, since they have both been shown to function in $B$. subtilis (Penschke et al., 1985). The $\lambda \mathrm{t}_{0}$ terminator can be isolated on a Sau3A fragment which on insertion at a BamHI site regenerates a $B a m \mathrm{HI}$ site at the downstream end of the terminator (see pAPG3, Fig. 1). However, downstream of the $r r n B t_{1} t_{2}$ terminators from pKK223-3 there is no convenient restriction site before the $b l a$ promoter at position 4189 of the pBR322 sequence (Brosius et al., 1982). To delete this promoter we used $B a l 31$ deletion starting from the $P v u I$ site in the bla gene (see construction of pAPG4 410 , Fig. 1) and inserted a $B a m \mathrm{HI}$ linker at the end of the deletion. The end-point of the deletion was determined by DNA sequence analysis to confirm the removal of the bla promoter. Thus the cassette is flanked by convenient restriction sites and should not carry promoters capable of initiating transcription into surrounding DNA.

To check the behaviour of the cassettes in B. subtilis the versions flanked by $B a m H I$ were inserted at the $B g / I I$ site within the $\mathrm{Km}^{\mathrm{R}}$ gene of pUB110. Transformation of B. subtilis yielded the expected $\mathrm{Cm}^{\mathrm{R}} \mathrm{Km}^{\mathrm{S}}$ plasmids but only bacteria carrying plasmids with the cassette in which $x y l E$ is expressed from the SPO2 promoter (designated cAPG1000) gave colonies that were easily distinguishable from plasmid-negative colonies by the yellow colour they developed when sprayed with a solution of catechol. Quantitative estimates of XylE activity in bacteria carrying PAPG111 and pAPG119 (which contain cAPG1000 in opposite orientations) indicated that the level was independent of the orientation of insertion. By comparisons with previously published data (Zukowski et al., 1983) we estimated that the SPO2 promoter should give enough $x y l E$ expression for the presence of the cassette to be detectable even if joined to a plasmid with a copy number of five copies per cell. 

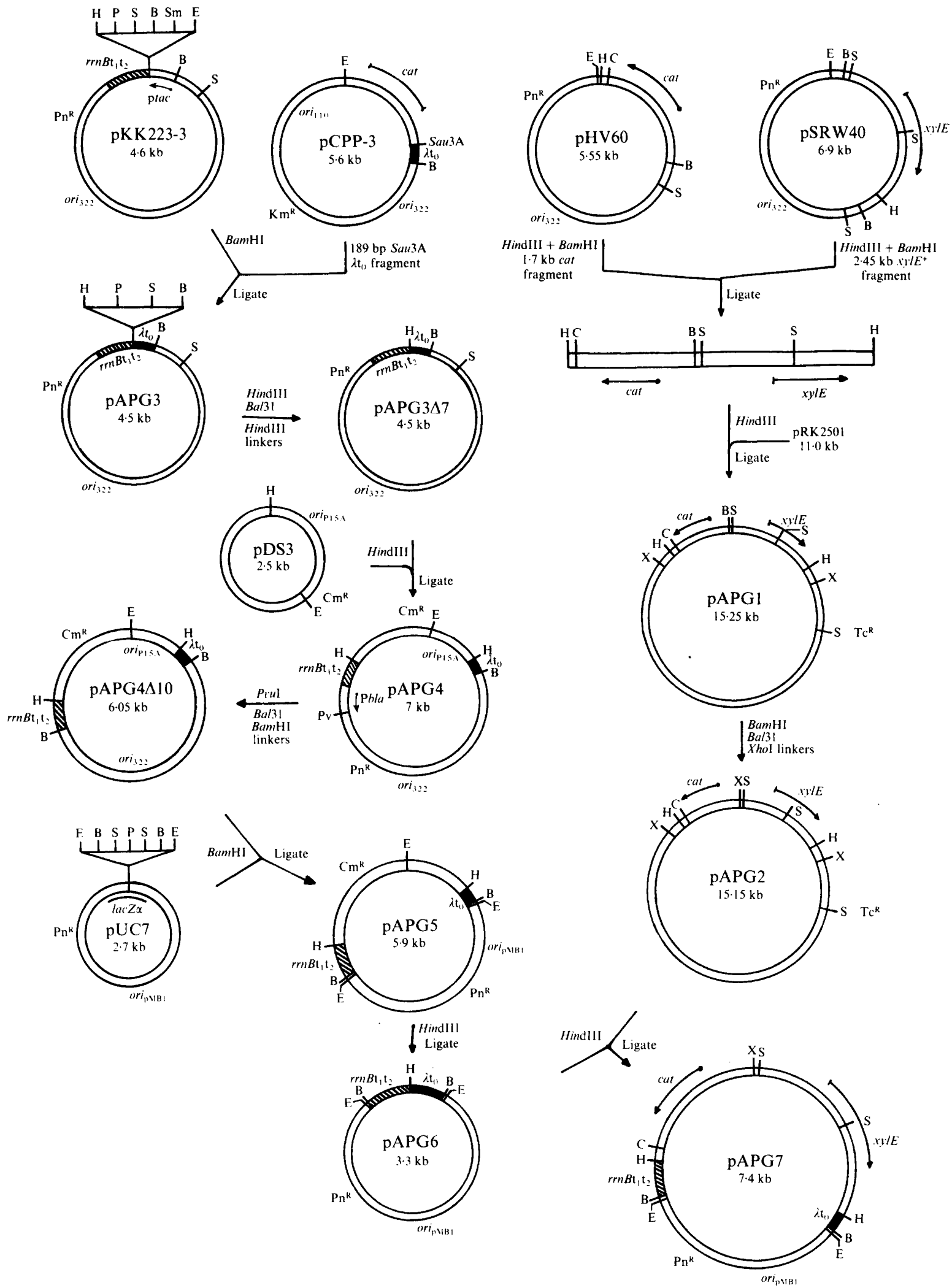

Fig. 1. Construction of the cassette cAPG1000. Restriction sites are shown as: BamHI, B; EcoRI, E; HindIII, H; PstI, P; PvuI, Pv; SalI, S; SmaI, Sm;XhoI, X. 
Insertion of the cassette $c A P G 1000$ into the cryptic endogenous B. subtilis plasmid pPOD2000 and approximate location of plasmid regions required for replication

A restriction map of pPOD2000 is shown in Fig. 2, using coordinates originating at the unique SalI site. Previous attempts to insert a selectable HindIII fragment into the HindIII sites of pPOD2000 gave insertions at all sites except that at coordinate $2.2 \mathrm{~kb}$, suggesting that this site lies within a region essential for replication. The EcoRI fragment of pAPG7 carrying CAPG1000 was ligated to the EcoRI fragment of pPOD2000 which runs from coordinate 0.9 to $4.7 \mathrm{~kb}$ and after transformation of $B$. subtilis 1A289, plasmid DNA from $\mathrm{Cm}^{\mathrm{R}} \mathrm{XylE}^{+}$colonies was analysed. Two different plasmids with the two possible orientations of $E c o$ RI fragments were found and designated pAPG2001 and pAPG2002. They both appear to have the same copy number as pPOD2000 (estimated as five copies per chromosome equivalent; $\mathrm{A}$. Mountain, unpublished), as estimated by yield of plasmid DNA extracted by the alkaline SDS method. We therefore concluded that a functional replication system with normal control elements is contained within this EcoRI fragment. By ligating pPOD2000 DNA which had been partially digested with HindIII to HindIII-digested pCT571 we obtained clones which contained various subsegments of pPOD2000. Testing these for replication in $B$. subtilis indicated that only the

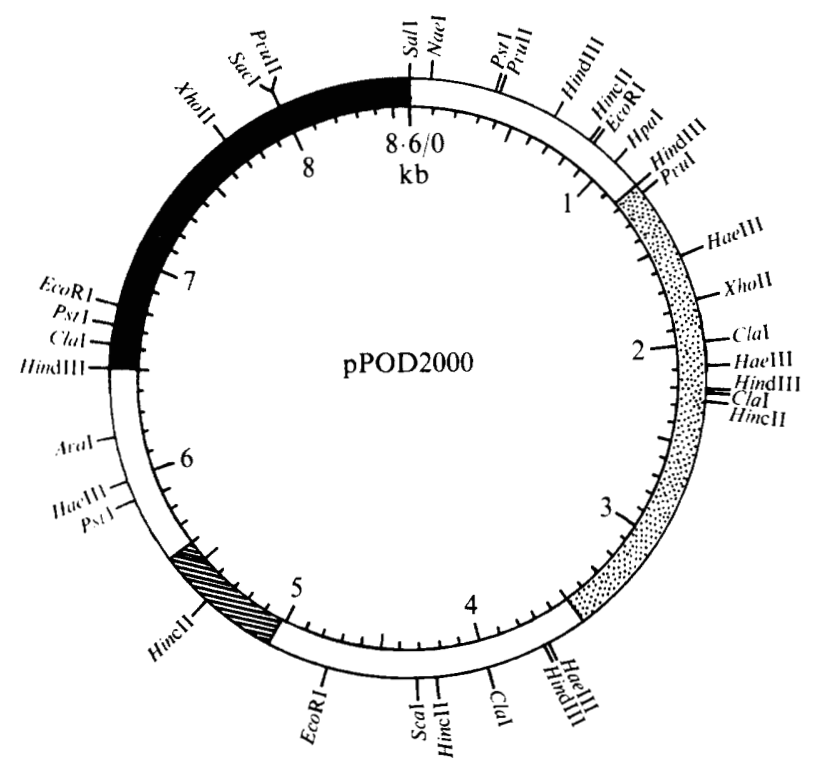

Fig. 2. Physical and preliminary genetic map of pPOD2000. An extensive restriction map of the plasmid is shown; the coordinates of the cleavage sites are given relative to the unique $S a l I$ site $(0 / 8.6 \mathrm{~kb})$. This study has identified the replication region (rep) (speckled sector), a region whose integrity is required for structural stability (stab) (hatched sector), and a region encoding functions involved in the segregational stability (seg/par) (solid sector) of pPOD2000. third- and fourth-largest HindIII fragments were necessary to allow autonomous replication, that neither on its own was sufficient and that the two fragments needed to be joined in their natural configuration. This further defines the replication system.

To obtain derivatives with cAPG1000 inserted at a range of positions, pPOD2000 DNA was partially digested with Sau3A, separated by agarose gel electrophoresis and the DNA species corresponding to fulllength linear plasmid DNA molecules purified. After dephosphorylation the DNA was ligated to purified cAPG1000 DNA produced by cleavage with BamHI. $B$. subtilis was transformed with this DNA and the plasmid DNA from $\mathrm{Cm}^{\mathrm{R}} \mathrm{XylE}^{+}$transformants was isolated and characterized by restriction endonuclease digestion and gel electrophoresis. Twenty insertion derivatives were analysed in detail (Fig. 3) and used for further study. Some of these appeared to be simple insertions of the cassette into the full-length plasmid while other insertion events were associated with deletions, some as large as $3.2 \mathrm{~kb}$. One of these deletions extends (in plasmid pPOD2029) from coordinate $3.5 \mathrm{~kb}$ to $6.0 \mathrm{~kb}$, removing the HindIII site at $3.7 \mathrm{~kb}$ and therefore further defining the replication region to between coordinates 1.2 and $3.5 \mathrm{~kb}$. The size of this region, $2.3 \mathrm{~kb}$, is in line with the size of minimal replicons found for many other plasmids. The absence of cassette insertions within this region compared to the disruption of the rest of the plasmid at many sites could be due to a relative deficiency of such sites within this region. However, this region cannot be completely devoid of such sites because it contains a $P v u I$ site and an XholI site, both of which are also Sau3A sites. Therefore the lack of insertions in this region suggests that most of the $2.3 \mathrm{~kb}$ is important for plasmid replication.

\section{Stability characteristics of pPOD2000::cAPG1000 hybrids}

To locate plasmid regions encoding functions which are important for stable inheritance in $B$. subtilis we screened cultures of $\mathrm{Rec}^{+}(1 \mathrm{~A} 289)$ B. subtilis carrying the derivatives shown in Fig. 3 for loss of plasmid markers during rounds of nonselective growth in batch culture for up to 100 generations. During this screening process we noticed that bacteria carrying hybrid plasmids containing all of the pPOD2000 DNA grew significantly more slowly than bacteria without such plasmids, both in liquid culture and on solid media. Quantification of this effect indicated that bacteria carrying hybrids containing most of pPOD2000 grew with a mean generation time $( \pm$ SEM) of $45 \pm 4.5 \mathrm{~min}$ compared to $29 \mathrm{~min}$ for plasmid-free bacteria. However, plasmids pAPG2001 and pAPG2002 affected bacterial growth rate much less, 

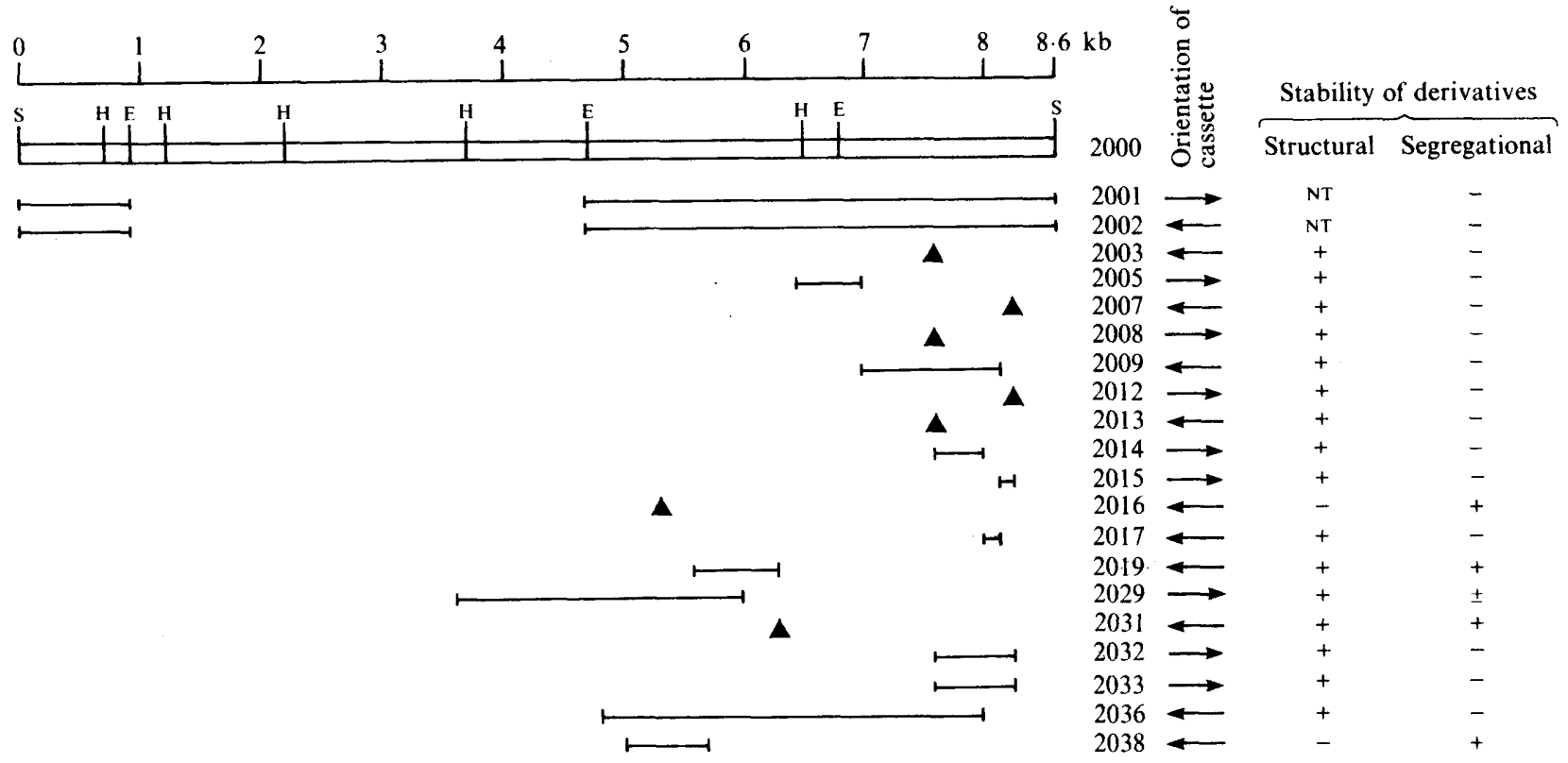

Fig. 3. Stability of pPOD2000::cAPG1000 derivatives. The open bar represents the entire pPOD2000 genome (8.6 kb) with the positions of the SalI (S), EcoRI (E) and HindIII (H) sites indicated. The pPOD2000-cAPG1000 hybrids (pAPG2001 to pAPG2038) are represented as follows: $\triangle$ indicates the insertion position of CAPG1000 into full-length pPOD2000; $\downarrow$ indicates the extent of the in vitro Sau3A deletion from the point of cAPG1000 insertion. The arrows indicate the orientation of cAPG1000 with respect to the direction of $x y l E$ transcription. For stability test: + , stable; - , unstable; \pm , only marginal instability; NT, not tested.

bacteria carrying them having a mean generation time of $33 \pm 1.5 \mathrm{~min}$. Since all the plasmids tested contain the cassette cAPG1000 this indicates that the retardation of growth rate is not due to the cassette but must be due to some plasmid-encoded function. Examination of plasmids retaining this growth-retarding effect suggests that the region of the plasmid from 8.3 to $1.0 \mathrm{~kb}$ plays some role in conferring this phenotype.

A consequence of this growth disadvantage is that the segregation kinetics for unstable plasmids will be determined by both the rate of appearance of plasmidfree bacteria and the relative rates at which plasmidpositive and plasmid-free bacteria grow. Since this complicates the detailed interpretation of results we initially confined ourselves to determining whether insertions and/or deletions caused structural or segregational instability.

The results of the stability tests are summarized in Fig. 3. A number of classes of phenotype can be identified. First, derivatives with cAPG1000 inserted at coordinates 5.6-6.3 kb and 6.3 kb (pAPG2019 and pAPG2031, respectively) gave no detectable plasmid loss over the 100 generations of the experiment. Thus pPOD2000 is very stably maintained and the cassette can be inserted at certain sites without disrupting its stable inheritance functions. Instability observed with the cassette inserted at other locations must therefore be due to disruption of actively required loci.

Second, an insertion/deletion between coordinates 5.0 and $5.7 \mathrm{~kb}(\mathrm{pPOD} 2038)$ and an insertion at coordinate $5 \cdot 3 \mathrm{~kb}$ (pPOD2016) resulted in plasmids which exhibited a high rate of structural instability but no segregational instability: they gave rise to $\mathrm{XylE}^{-}$colonies all of which were $\mathrm{Cm}^{\mathrm{R}}$. This instability was also observed when the experiment was repeated in the recE strain BD224 (data not shown), indicating that the structural instability is RecE-independent. Since a deletion from $5.6 \mathrm{~kb}$ to $6.3 \mathrm{~kb}$ has no effect on stability (pAPG2019), the locus affected in pAPG2016 and pAPG2038 must extend no further than coordinate $5.6 \mathrm{~kb}$. However, if there is a specific locus in this region whose inactivation leads to structural instability then the function it provides is either not essential or can be fulfilled by other loci since the plasmid pAPG2029 with a deletion from 3.6 to $6.0 \mathrm{~kb}$ resulted in only minor segregational instability and no structural instability.

Third, a series of insertions/deletions in the region of coordinates $6.45-8.25 \mathrm{~kb}$ had no effect on structural stability but resulted in significant segregational instability. A majority of these plasmids, which have simple insertions or only small deletions affecting this region (pAPG2003, 2005, 2007, 2008, 2012-2015, 2017, 2032, 2033), resulted in less than $1 \%$ plasmid retention after 100 generations. However, hybrids pAPG2009 (deletion from 7.0 to $8.15 \mathrm{~kb}$ ) and pAPG2036 (deletion from 4.8 to $8.15 \mathrm{~kb}$ ), while still segregating at a high rate, were significantly less unstable than the majority of these derivatives (about $10 \%$ and $4 \%$ plasmid retention, 
respectively, after 100 generations). This may suggest that partial removal of the functions in this region has a greater effect on plasmid stability than complete removal.

\section{Discussion}

We have shown that the cassette cAPG1000 fulfils our predetermined requirements. The cassette carries both a useful selectable marker and a marker whose presence in the bacteria of a colony, even when carried on a relatively low-copy-number plasmid, can easily be detected. Except where the cassette actually disrupts a region important for plasmid stability, insertion of the cassette into pPOD2000 yielded derivatives with no detectable rate of loss. Since the presence of these plasmids appears to increase the mean generation time of host bacteria by about $50 \%$, even a very low rate of segregation of plasmid-free bacteria should have been detectable if it were occurring. Since pPOD2000 can accommodate insertion of at least $5 \mathrm{~kb}$ of DNA with no significant destabilization, the stable derivatives described in this paper therefore provide the basis for the development of novel cloning vectors with sites for insertion of foreign DNA within the cassette.

DNA sequence analysis of the rep region (A. P. Gleave, unpublished) indicates that pPOD2000 belongs to the $\mathrm{pC} 194$ family of plasmids, which replicate by a rolling circle mechanism. Insertions into one of the stability regions identified results in structural instability and by analogy with other members of the pC194 may represent a region involved in lagging strand synthesis during replication (te Riele et al., 1986a, b; Gruss et al., 1987; Viret \& Alonso, 1987). The accumulation of singlestranded DNA resulting from inactivation of such a locus could stimulate deletion formation (Ehrlich et al., 1986). While we have been unable to detect singlestranded plasmid DNA in cells carrying pPOD2000 (A. P. Gleave, unpublished) we have not yet determined whether or not unstable derivatives of this sort now accumulate single-stranded DNA as would be predicted.

Insertions into a second region result in segregational instability. Given the low copy number of pPOD2000 it is unlikely that all daughter cells would receive plasmid copies by random segregation. Therefore the region is likely to encode some sort of active partitioning mechanism. It is interesting that the data suggest that complete removal of this region results in less instability than the majority of more limited insertions/deletions in this region. Such a phenomenon has previously been observed with the par functions of the mini P1 plasmid (Funnell, 1988) and was attributed to the individual subcomponents of the par system actively interfering with the random partitioning of the plasmid DNA molecules. However, this region of pPOD2000 may also provide a function which results in death of bacteria that have lost the plasmid, as has been observed for some lowcopy-number plasmids of Gram-negative bacteria (Jaffé et al., 1985; Gerdes et al., 1986). Whatever the underlying mechanism of the stability function(s) of pPOD2000, their efficiency suggests a system not previously described for plasmids of Gram-positive bacteria. Therefore, elucidation of the nature of these functions and their relationship to analogous systems of Gram-negative bacteria will be of considerable fundamental and applied interest.

A.P.G. was the recipient of an SERC CASE Award in collaboration with Apcel/Celltech Ltd

\section{References}

Band, L., Yansura, D. G. \& Henner, D. J. (1983). Construction of a vector for cloning promoters in Bacillus subtilis. Gene 26, 313-315.

BIRnBoIm, H. C. \& Doly, J. (1979). A rapid alkaline extraction procedure for screening recombinant plasmid DNA. Nucleic Acids Research 7, 1513-1523.

BRoN, S. \& LUXEN, E. (1985). Segregational instability of pUB110derived recombinant plasmids in Bacillus subtilis. Plasmid 14, 235244.

Bron, S., Bosma, P., van Belkam, M. \& Luxen, E. (1987). Stability function in the Bacillus subtilis plasmid pTA1060. Plasmid 18, 8-15.

Brosius, J. \& Holy, A. (1984). Regulation of ribosomal RNA promoiers with a synthetic lac operator. Proceedings of the National Academy of Sciences of the United States of America 81, 6929-6933.

Brosius, J., Cate, R. L. \& Perlmutter, A. P. (1982). Precise location of two promoters for the $\beta$-lactamase gene of pBR322. Journal of Biological Chemistry 257, 9205-9210.

Chang, S., Chang, S.-Y. \& Gray, O. (1987). Structural and genetic analyses of a par locus that regulates partition in Bacillus subtilis. Journal of Bacteriology 169, 3952-3962.

EHRLICH, S. D. (1977). Replication and expression of plasmids from Staphylococcus aureus in Bacillus subtilis. Proceedings of the National Academy of Sciences of the United States of America 74, 1680-1682.

Ehrlich, S. D., te Riele, H., Petit, M. A., JANniere, L., Noirot, P. \& Michel, B. (1986). DNA recombination in plasmids and the chromosome of Bacillus subtilis. In Bacillus Molecular Genetics and Biotechnology Applications, pp. 27-33. Edited by A. T. Ganesan \& J. A. Hoch. New York. Academic Press.

FunNell, B. E. (1988). Mini-Pl plasmid partitioning. Excess Par B protein destabilizes plasmids containing the centromere par $\mathrm{S}$. Journal of Bacteriology 170, 954-960.

Gerdes, K., Rasmussen, P. B. \& Molin, S. (1986). Unique type of plasmid maintenance function : postsegregational killing of plasmidfree cells. Proceedings of the National Academy of Sciences of the United States of America 83, 3116-3120.

Gornall, A. G., Bardawill, C. J. \& David, M. M. (1949). Determination of serum proteins by means of the biuret reaction. Journal of Biological Chemistry 177, 751-766.

Grandi, G., MotTes, M. \& Sgaramella, V. (1981). Specific pattern of instability of Escherichia coli His G gene cloned into Bacillus subtilis via the Staphylococcus aureus plasmid pCS194. Plasmid 6, 99-111.

Gros, M. F., TE RIELE, H. \& EHRLICH, S. D. (1987). Rolling circle replication of single stranded DNA plasmid pC194. EMBO Journal 6, 3863-3869.

Gruss, A., Ross, H. F. \& Novick, R. P. (1987). Functional analysis of a palindromic sequence required for normal replication of several 
staphylococcal plasmids. Proceedings of the National Academy of Sciences of the United States of America 84, 2165-2169.

GrycZan, T. J. \& DubNAU, D. (1978). Construction and properties of chimeric plasmids in Bacillus subtilis. Proceedings of the National Academy of Sciences of the United States of America 75, 1428-1432.

Gryczan, T. J., Shrivakumar, A. G. \& Dubnau, D. (1980). Characterization of chimeric plasmid cloning vehicles in Bacillus subtilis. Journal of Bacteriology 141, 246-253.

Hasnain, S. \& Thomas, C. M. (1986). Construction of a novel gene bank of Bacillus subtilis using a low copy number vector in Escherichia coli. Journal of General Microbiology 132, 1863-1874.

JAFFÉ, A., OgurA, T. \& HiRAGA, S. (1985). Effects of the $c c d$ function of the F plasmid on bacterial growth. Journal of Bacteriology 163, 841-849.

Kahn, M., Kolter, R., Thomas, C. M., Figurski, D., Meyer, R., Remaut, E. \& Helinski, D. R. (1979). Plasmid cloning vehicles derived from plasmids ColE1, F, R6K, and RK2. Methods in Enzymology 68, 268-280.

KREFT, J., Bernard, K. \& Goebel, W. (1982). Recombinant plasmids capable of replication in B. subtilis and E. coli. Molecular and General Genetics 162, 59-67.

Maniatis, T., Fritsch, E. F. \& SAmbrook, J. (1982). Molecular Cloning: a Laboratory Manual. Cold Spring Harbor, NY: Cold Spring Harbor Laboratory.

MAXAM, A. M. \& GILBERT, W. (1980). Sequencing end-labelled DNA with base-specific cleavage. Methods in Enzymology 65, 449-560.

Meyer, R., Figurski, D. \& Helinski, D. R. (1977). Physical and genetic studies with restriction endonucleases on the broad host range plasmid RK2. Molecular and General Genetics 152, 129-135.

OstrofF, G. R. \& PÈnE, J. J. (1983). Molecular cloning with bifunctional plasmid vectors in Bacillus subtilis. Journal of Bacteriology 156, 934-936.

Palva, I., Lehtovaara, L. V., Sibakiv, M., Cantell, K., Schein, C. H., Kashiwagi, K. \& Weissman, C. (1983). Secretion of interferon by Bacillus subtilis. Gene 22, 229-235.

Penschke, U., Beuck, V., Bujard, H., Gentz, R. \& LeGrice, S. F. J. (1985). Efficient utilisation of Escherichia coli transcriptional signals in Bacillus subtilis. Journal of Molecular Biology 186, 547-555.

Primrose, S. B. \& EhrLICH, S. D. (1981). Isolation of plasmid deletion derivatives and a study of their instability. Plasmid 6, 193-201.
TE Riele, H., Michel, B. \& Ehrich, S. D. (1986a). Single stranded plasmid DNA in Bacillus subtilis and Staphylococcus aureus. Proceedings of the National Academy of Sciences of the United States of America 83, 2541-2545.

TE Riele, H., Michel, B. \& Ehrlich, S. D. (1986b). Are single stranded circles intermediates in plasmid DNA replication? EMBO Journal 5, 631-637.

Sala-Trepat, J. M. \& Evans, W. C. (1971). The meta-cleavage of catechol by Azotobacter species. European Journal of Biochemistry 20 , 400-413.

SMIth, C. A. \& Thomas, C. M. (1984). Nucleotide sequence of the $\operatorname{trf} A$ gene of broad host range plasmid RK2. Journal of Molecular Biology 175, 251-262.

Tanaka, T., Kuroda, M. \& SaKaguchi, K. (1977). Isolation and characterization of four plasmids from Bacillus subtilis. Journal of Bacteriology 129, 1487-1494.

Thomas, C. M. (1981). Complementation analysis of replication and maintenance functions of broad host range plasmids RK2 and RP1. Plasmid 5, 277-291.

Vieira, J. \& Messing, J. (1982). The pUC plasmids, an M13mp7derived system for insertion mutagenesis and sequencing with synthetic universal primers. Gene 19, 259-268.

VIRET, J. F. \& ALONSO, J. C. (1987). Generation of linear multigenomelength plasmid molecules in Bacillus subtilis. Nucleic Acids Research 15, 6349-6367.

WARNE, S. R. (1986). Studies of gene expression signals suitable for the regulated products of foreign proteins in Escherichia coli and Pseudomonas species. PhD thesis, University of Birmingham, UK.

Williams, D. M., Duvall, E. J. \& Lovett, P. S. (1981). Cloning restriction fragments that promote expression of a gene in Bacillus subtilis. Journal of Bacteriology 146, 1162-1165.

Yoshimura, K., Yamamoto, O., Seki, T. \& Oshimi, Y. (1983). Distribution of heterogeneous and homologous plasmids in Bacillus spp. Applied and Environmental Microbiology 46, 1268-1275.

Zukowski, M. M., Gaffney, D. F., SPECK, D., KauffmanN, M., Findeli, A., Wisecup, A. \& LeCoce, J. P. (1983). Chromogenic identification of genetic regulatory signals in Bacillus subtilis based on expression of a cloned Pseudomonas gene. Proceedings of the National Academy of Sciences of the United States of America $\mathbf{8 0}$, 1101-1105. 